\title{
Utilization of Cement Kiln Dust (CKD) with Silica Fume (SF) as a Partial Replacement of Cement in Concrete Production
}

\author{
Arafa Elsayed Elhelloty, Mohammed Taha Nooman*, Rafik Khairy Abdelwahab, \\ Ahmed Islam Abdullah
}

Civil Engineering Department, Faculty of Engineering, Al-Azhar University, Cairo, Egypt

Email: *nooman1966@yahoo.com

How to cite this paper: Elhelloty, A.E., Nooman, M.T., Abdelwahab, R.K. and Abdullah, A.I. (2019) Utilization of Cement Kiln Dust (CKD) with Silica Fume (SF) as a Partial Replacement of Cement in Concrete Production. Journal of Minerals and Materials Characterization and Engineering, 7, 137-149.

https://doi.org/10.4236/jmmce.2019.74010

Received: May 5, 2019

Accepted: May 26, 2019

Published: May 29, 2019

Copyright $\odot 2019$ by author(s) and Scientific Research Publishing Inc. This work is licensed under the Creative Commons Attribution International License (CC BY 4.0).

http://creativecommons.org/licenses/by/4.0/

c) (i) Open Access

\begin{abstract}
This research aimed to clarify the role of by-product materials, such as CKD with SF as partial replacement by weight of cement in concrete manufacturing and inclusion on different characteristics of concrete. Concrete test specimens were mixed with $0 \%, 5 \%, 10 \%, 15 \%, 20 \%$ and $25 \%$ (CKD) with $15 \%$ (SF) as partial replacement by weight of Cement (CEM I-52.5N). Fresh concrete properties have been evaluated by workability measurement slump test. While hardened concrete properties have been evaluated by compressive, split tensile and flexural strengths tests at ages 7, 28 and 56 days, but evaluated for bond strength, modulus of elasticity and chemical composition measurement with X-Ray Fluorescence at age of 28 days. The test results have revealed that the increase of CKD amount with fixed amount of SF in concrete mixtures as partial replacement by weight of cement leads to gradual decrease of fresh concrete workability. In concrete mixtures, 20\% CKD in the presence of $15 \% \mathrm{SF}$ as partial replacement by the weight of cement are the optimum ratios which can be used without any negative effect on mechanical properties compressive, indirect tensile, flexural and bond strength at all the ages of concrete. Also modulus of elasticity and bond strength increased by $8.81 \%$ and $0.69 \%$ respectively at the age 28 days compared with control mixture.
\end{abstract}

\section{Keywords}

Partial Replacement of Cement, Cement Kiln Dust (CKD), Silica Fume (SF), Properties of Fresh and Hardened Concrete, Modulus of Elasticity, Bond Strength, XRF 


\section{Introduction}

$\mathrm{CKD}$ is an industrial by-product material during cement manufacturing that is not returned to the process but disposes of them by landfill. It was found from the experimental tests and previous research, the utilization of CKD individually as the partial replacement of cement in concrete leads to decreases in all types of strength. Also silica fume is an industrial by-product material derived during production of elemental silicon where it is defined as an alloy containing silicon; its noncrystalline silica is very fine which is produced in electric arc furnaces [1]. From experimental program, it was observed that the utilization of CKD with SF does not have any negative effects on the strength of concrete to a certain limit, but improves its performance. Therefore, it was necessary to study fresh and hardened concrete properties in the case of a partial replacing of cement with CKD and SF in the production of concrete, and determine optimum ratios for replacement. Generally increasing CKD amount leads to reduction of fresh mixes workability and also strength of hardened mortars and concretes [2]. It was observed in CKD with cement blends; the gain contribution of CKD strength is low [2]. The use of CKD as a partial replacing of cement possible in the combination with pozzolanic materials in the certain mortar mixed designs without decreasing in the main characteristics of the product [3]. The pozzolanic material such as SF is an ultra-fine powder and very reactive pozzolana; it is used in concrete because of its fine particles, large surface area and higher $\mathrm{SiO}_{2}$ content [4]. Silica fume as a pozzolanic material, when properly utilized as certain percent, can enhance the various properties of concrete both in the fresh state as well as in hardened state such as cohesiveness, strength, permeability and durability [5]. In the general applications, part of cement may be replaced by a much smaller quantity of silica fume. For example, one part of cement can be replaced with 0.25 to 0.33 part of silica fume (mass to mass) without losing in the strength, provided the content of water remains constant [6].

\section{Experimental Program}

\subsection{Materials Used}

According to the Egyptian standard specifications for concrete aggregates [7], sand with fineness modulus equal 2.59 and specific gravity of 2.57 was used, whereas the coarse aggregate used was dolomite maximum normal size (5 - 14 $\mathrm{mm}$ ) and specific gravity of 2.74. Cement (CEM I-52.5N) used was fresh product from Sina factory and complies to E.S.S 4756/2013 [8]. CKD was obtained from the El Nahda cement factory in Qena, Egypt. SF was obtained from Egyptian Company for Ferroalloys (Alferrosilicon), Edfo factory, Aswan, Egypt. SF was confirming to ACI 234R-96 [6]. The chemical composition of Portland cement, CKD and SF were shown in Table 1. Potable water free from salts, oils, acids, sugars and other harmful substances was used for mixing and curing of specimens. Sikament-163M was used as super plasticizer (SP), for highly effective water reducing agent, density $\left(\right.$ at $\left.20^{\circ} \mathrm{C}\right) 1.200 \pm 0.005 \mathrm{~kg} / \mathrm{liter}(\mathrm{ASTM}$ C494), 
Table 1. Chemical composition of cement, cement kiln dust and silica fume.

\begin{tabular}{cccc}
\hline \multirow{2}{*}{$\begin{array}{c}\text { Chemical } \\
\text { Composition, }\end{array}$} & \multicolumn{3}{c}{ Sample } \\
\cline { 2 - 4 } & CEM I $(52.5 \mathrm{~N})$ & Cement kiln dust (CKD) & Silica fume $^{\star}(\mathrm{SF})$ \\
\hline $\mathrm{SiO}_{2}$ & 20.48 & 12.27 & 93.79 \\
$\mathrm{Al}_{2} \mathrm{O}_{3}$ & 15.06 & 2.27 & 0.36 \\
$\mathrm{Fe}_{2} \mathrm{O}_{3}$ & 5.23 & 3.70 & 1.48 \\
$\mathrm{CaO}$ & 3.96 & 45.28 & 0.33 \\
$\mathrm{MgO}$ & 3.40 & 1.49 & 0.41 \\
$\mathrm{SO}_{3}$ & 2.12 & 2.59 & 0.19 \\
$\mathrm{Na}_{2} \mathrm{O}$ & 62.72 & 0.31 & 0.43 \\
$\mathrm{~K}_{2} \mathrm{O}$ & 1.67 & 5.68 & 0.62 \\
$\mathrm{Cl}$ & 3.20 & 8.06 & 0.05 \\
L.O.I & 0.33 & 17.38 & 1.63 \\
\hline
\end{tabular}

${ }^{*}$ Note: These average values are supplied by the manufacturer.

Appearance/Colour is brown liquid and recommended dosage is $0.6 \%-2.5 \%$ by weight of cement. The experimental dosage was $2.0 \%$ by weight of cement.

\subsection{Mixtures Proportions and Specimens' Details}

In this experimental investigation, control concrete mix to achieve compressive strength of $50 \mathrm{~N} / \mathrm{mm}^{2}$ at the age of 28 days was done according to ECP 203-2007 [9]. The use CKD with different percentages 5\%, 10\%, 15\%, 20\% and 25\% and a fixed proportion of silica fume (SF) $15 \%$ as partial replacement by the weight of (OPC). The mixtures proportions for $1 \mathrm{~m}^{3}$ in all concrete mixtures were shown in Table 2. Slump test was done on the fresh concrete to find its consistency and workability. For every mix, cubes $(150 \mathrm{~mm} \times 150 \mathrm{~mm} \times 150 \mathrm{~mm})$ were cast for the compressive strength tests, cylinders (Diameter; $150 \mathrm{~mm}$ and height; 300 $\mathrm{mm}$ ) were cast for the split tensile strength and modulus of elasticity tests and prisms $(100 \mathrm{~mm} \times 100 \mathrm{~mm} \times 500 \mathrm{~mm})$ were cast for the flexural strength tests. The Bond test for reinforcing steel describes by pull-out specimen as a steel reinforcing bar $12 \mathrm{~mm}$ diameter embedded in concrete cylinder (Diameter; 150 $\mathrm{mm}$ and height; $300 \mathrm{~mm}$ ), An anchorage length equal to $300 \mathrm{~mm}$. After casting, all specimens were left in the forms for 24 hours before demoulding. The curing of specimens was done by placing all specimens in water basins until the ages of testing.

\section{Analysis of Test Results}

\subsection{Workability of Fresh Concrete}

The concrete slump flow test was used according to Egyptian Code for the design and implementation of concrete structures, tests guide C203 to determine fresh concrete workability [10]. Table 3 shows slump test results for all mixtures, in general a decrease in slump were observed with increase ratio of CKD 
Table 2. Mixtures proportions.

\begin{tabular}{cccccccc}
\hline Mix & $\begin{array}{c}\text { Cement } \\
\left(\mathrm{kg} / \mathrm{m}^{3}\right)\end{array}$ & $\begin{array}{c}\text { water } \\
\left(\mathrm{kg} / \mathrm{m}^{3}\right)\end{array}$ & $\begin{array}{c}\text { crushed stone } \\
\left(\mathrm{kg} / \mathrm{m}^{3}\right)\end{array}$ & $\begin{array}{c}\text { sand } \\
\left(\mathrm{kg} / \mathrm{m}^{3}\right)\end{array}$ & $\begin{array}{c}\mathrm{CKD} \\
\left(\mathrm{kg} / \mathrm{m}^{3}\right)\end{array}$ & $\begin{array}{c}\text { SF } \\
\left(\mathrm{kg} / \mathrm{m}^{3}\right)\end{array}$ & $\begin{array}{c}\mathrm{SP} \\
\left(\mathrm{kg} / \mathrm{m}^{3}\right)\end{array}$ \\
\hline Mix-00-00 & 360 & 144 & 1260 & 630 & 0.0 & 0.0 & 7.2 \\
Control Mixture \\
Mix-05-15 & 288 & 144 & 1260 & 630 & 18 & 54 & 7.2 \\
Mix-10-15 & 270 & 144 & 1260 & 630 & 36 & 54 & 7.2 \\
Mix-15-15 & 252 & 144 & 1260 & 630 & 54 & 54 & 7.2 \\
Mix-20-15 & 234 & 144 & 1260 & 630 & 72 & 54 & 7.2 \\
Mix-25-15 & 216 & 144 & 1260 & 630 & 90 & 54 & 7.2 \\
\hline
\end{tabular}

${ }^{*}$ Mix designation is (Mix-CKD\%-SF\%).

Table 3. Slump test results.

\begin{tabular}{cc}
\hline Mix & Slump height $(\mathrm{mm})$ \\
\hline Mix-00-00 & 42 \\
Mix-05-15 & 36 \\
Mix-10-15 & 31 \\
Mix-15-15 & 25 \\
Mix-20-15 & 20 \\
Mix-25-15 & 16 \\
\hline
\end{tabular}

with SF. The results indicate that CKD with SF leads to decrease the fresh concrete workability. The increase of (CKD) amount, reduces the fresh mixes workability and also the strength of hardened mortars and concretes in generally [2]. The workability of fresh concrete decreases with increase of silica fume amount in concrete. For getting equal workability, the concrete containing of silica fume will tend to shows less slump height than conventional concrete [11]. For each level of $\mathrm{w} / \mathrm{b}$ ratio, the measured slump was the same or it decreased as the amount of CKD replacement level increased. As w/b ratio increased, the impact of CKD replacement of Portland cement on slump loss became more significant [12]. For obtained ordinary consistency with increase CKD amount, this required to increasing water, slump loss may be to high amounts of lime, sulfates, alkalis and volatile salts that require more water in concrete [13].

\subsection{Compressive Strength}

The test is conducted in Compression Testing Machine with a capacity of 2000 $\mathrm{kN}$ and loading rate $0.6 \mathrm{~N} / \mathrm{mm}^{2} / \mathrm{sec}$, according to Egyptian Code for the design and implementation of concrete structures, tests guide C203 [11]. Figure 1 shows the variation of compressive strength in CKD with SF mixtures when 


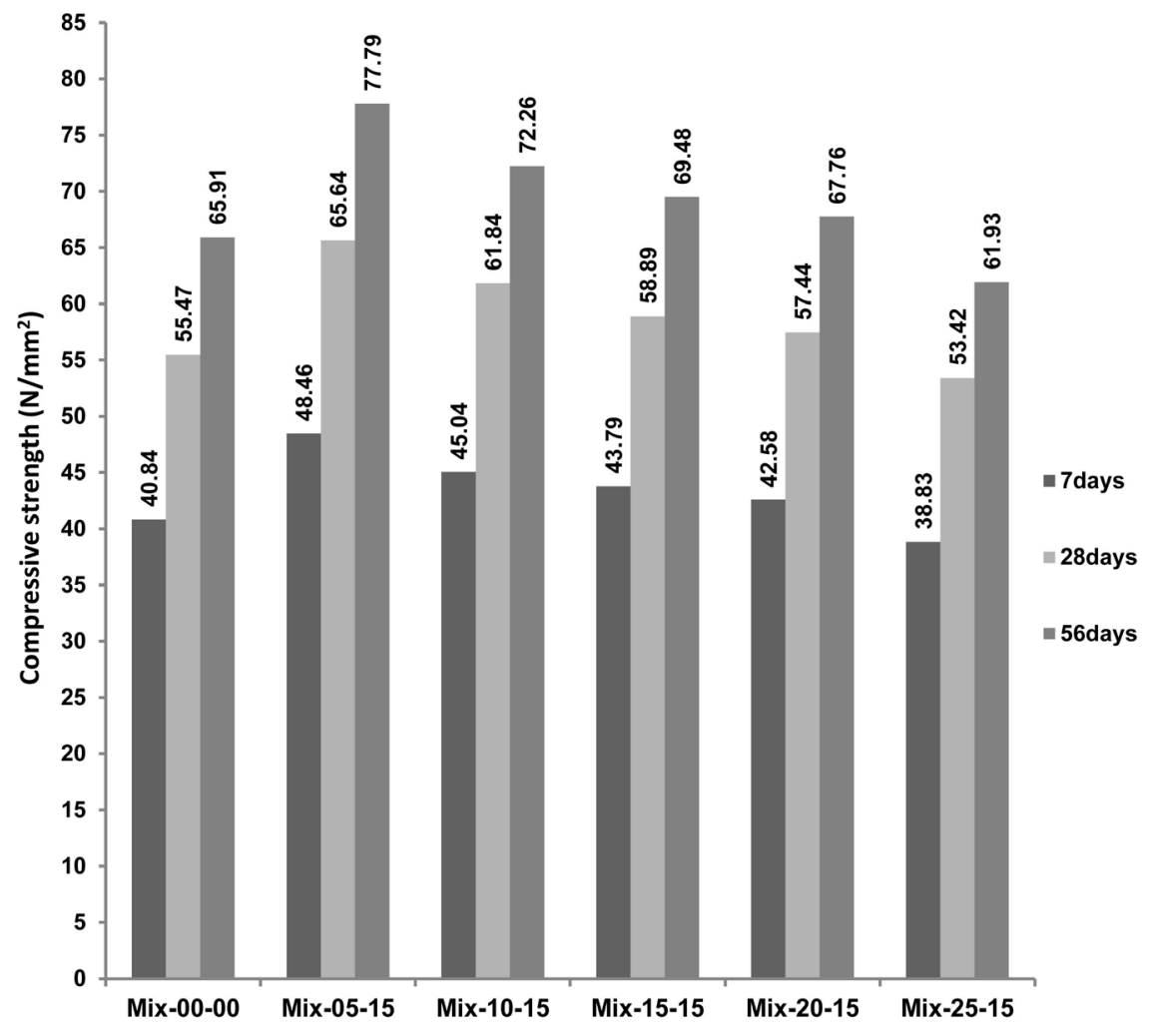

Figure 1. Compressive strength of mixtures contained cement kiln dust (CKD) 5\%, 10\%, $15 \%, 20 \%$ and $25 \%$ with constant $15 \%$ silica fume(SF), compared with control mixture $0 \%$ CKD with $0 \%$ SF After 7, 28 and 56 days.

compared with control mixture Mix-00-00. At all mixtures that have CKD with SF, The presence of SF with CKD lead to improve the strength up to $20 \%$ CKD. In mixtures Mix-05-15, Mix-10-15, Mix-15-15 and Mix-20-15, the maximum ratio of increase at different ratios of CKD with $15 \%$ SF are $18.66 \%, 10.28 \%, 7.22 \%$ and $4.24 \%$ respectively after 7 days, $18.34 \%, 11.48 \%, 6.17 \%$ and $3.55 \%$ respectively after 28 days and $18.02 \%, 9.63 \%, 5.42 \%$ and $2.81 \%$ respectively after 56 days. In mixture Mix-25-15 the strength values decrease with $4.93 \%$ after 7 days, $3.69 \%$ after 28 days and $6.05 \%$ after 56 days. Compressive strength of concrete mixtures were decreased with the increase in CKD percentage at the age 28 days, the reduction in strength at $10 \%$ and $40 \%$ CKD are $15 \%$ and $44 \%$ respectively [14]. The optimum replacement percentage of SF varies from $10 \%$ to $15 \%$. Compressive strength of concrete decreases when the cement replacing is above $15 \%$ of SF [11].

\subsection{Indirect Tensile Strength}

Indirect tensile strength was described by split tensile strength, the test is conducted in Compression Testing Machine with a capacity of $2000 \mathrm{kN}$ and loading rate $0.04 \mathrm{~N} / \mathrm{mm}^{2} / \mathrm{sec}$, according to Egyptian Code for the design and implementation of concrete structures, tests guide C203 [11]. Figure 2 shows the variation of split tensile strength in CKD with SF mixtures when compared with 


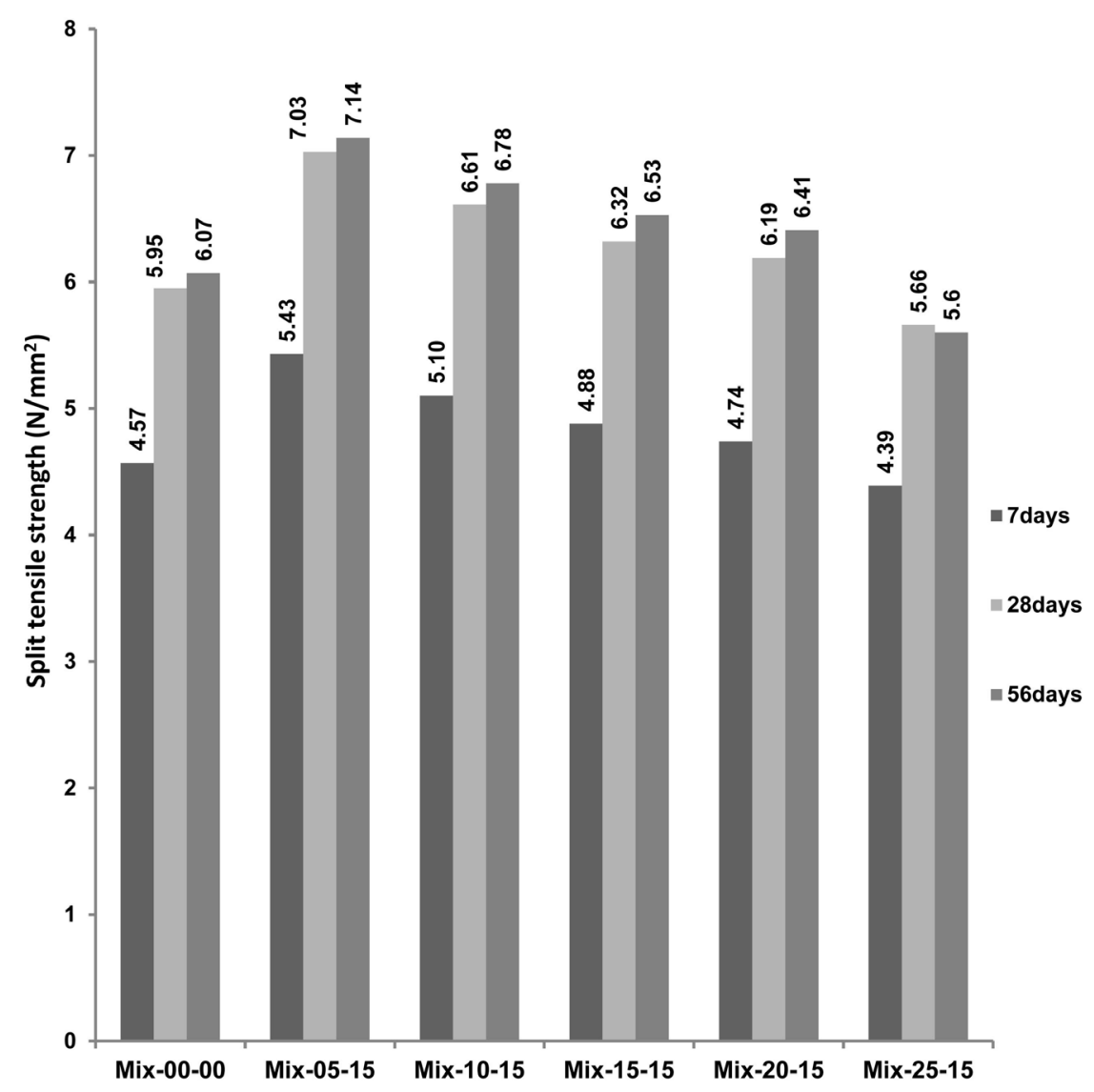

Figure 2. Split tensile strength of mixtures contained cement kiln dust (CKD) 5\%, 10\%, $15 \%, 20 \%$ and $25 \%$ with constant $15 \%$ silica fume(SF), compared with control mixture $0 \%$ CKD with $0 \%$ SF After 7, 28 and 56 days.

control mixture Mix-00-00. At all mixtures that have CKD with SF, the presence of SF with CKD lead to improve the strength up to $20 \%$ CKD. In mixtures Mix-05-15, Mix-10-15, Mix-15-15 and Mix-20-15, the maximum ratio of increase at different ratios of CKD with 15\% SF are 18.82\%, 11.53\%, 6.60\%, 3.71\% respectively after 7 days, $18.15 \%, 11.14 \%, 6.18 \%$ and $3.96 \%$ respectively after 28 days and $17.63 \%, 11.71 \%, 7.61 \%$ and $5.59 \%$ respectively after 56 days. In mixture Mix-25-15 the strength values decrease with $4.12 \%$ after 7 days, $4.91 \%$ after 28 days and $7.69 \%$ after 56 days. By the increase in CKD content, compressive strength, split tensile strength and also modulus of rupture was decreased [15]. Beyond $15 \%$ silica fume when replacement with cement in concrete, the increased in split tensile strength is almost insignificant. But get sizeable gains in the flexural strength was occurred even up to $25 \%$ silica fume replacement [16].

Relationship between Split Tensile Strength and Compressive Strength By analysis of the present test results, the relationship between the split tensile and compressive strengths of (CKD with SF) concrete mixtures after 28 days, it was found within range of $10.6 \%$ to $10.76 \%$, whereas $10.73 \%$ for control mixture. 


\subsection{Flexural Strength}

All prism specimens were tested under four point static load according to Egyptian Code for the design and implementation of concrete structures, tests guide C203 [11], by using a $1000 \mathrm{kN}$ capacity (loading rate $0.06 \mathrm{~N} / \mathrm{mm}^{2} / \mathrm{sec}$ ) hydraulic jack mounted on a steel frame in the R.C laboratory of Al-Azhar university. Figure 3 shows the variation of flexural strength in CKD with SF mixtures when compared with control mixture Mix-00-00. At all mixtures that have CKD with SF, the presence of SF with CKD lead to improve the strength up to $20 \%$ CKD. In mixtures Mix-05-15, Mix-10-15, Mix-15-15 and Mix-20-15, the maximum ratio of increase at different ratios of CKD with $15 \%$ SF are $17.27 \%, 11.36 \%, 7.27 \%$, $3.64 \%$ respectively after 7 days, $17.03 \%, 11.15 \%, 7.35 \%$ and $4.41 \%$ respectively after 28 days and $18.19 \%, 10.92 \%, 5.63 \%$ and $2.82 \%$ respectively after 56 days. In mixture Mix-25-15 the strength values decrease with 5.45\% after 7days, $4.41 \%$ after 28 days and $5.63 \%$ after 56 days. It was observed both of flexural strength and toughness values are decreased with the increase in CKD replacement ratios, but at $5 \%$ and $10 \%$ replacement ratios did not have an appreciable adverse effect, it is especially clear at low w/b ratios [12]. The reduction in flexural strength and toughness values attributed to a reduction in the cement amount in the blends as the content of CKD increased [11]. Content of $15 \%$ silica fume as partial replacement of cement were the optimum amount to significantly flexural strength enhancement [17].

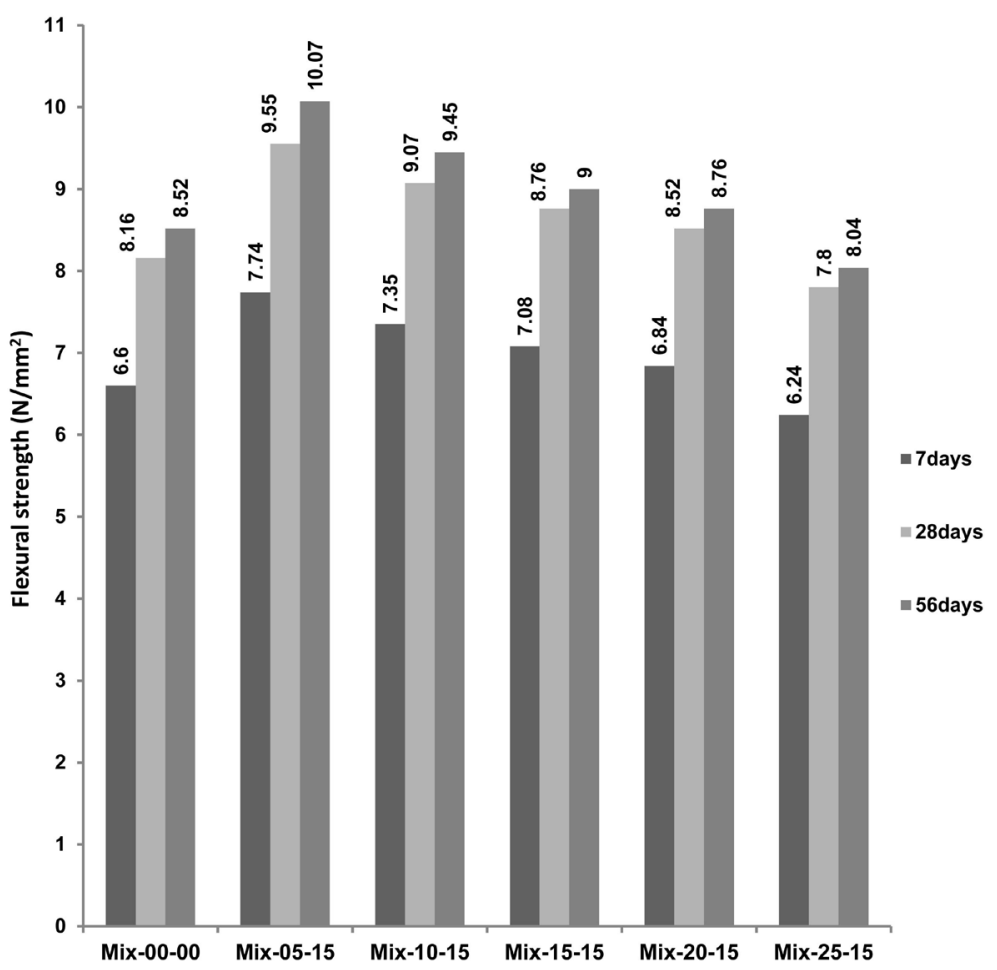

Figure 3. Flexural strength of mixtures contained cement kiln dust (CKD) 5\%, 10\%, 15\%, $20 \%$ and $25 \%$ with constant $15 \%$ silica fume (SF), compared with control mixture $0 \%$ CKD with $0 \%$ SF After 7, 28 and 56 days. 
Relationship between Flexural Strength and Compressive Strength By analysis of the present test results, the relationship between flexural and compressive strengths of (CKD with SF) concrete mixtures after 28 days, it was found within range $14.55 \%$ to $14.88 \%$, whereas $14.71 \%$ for control mixture.

\subsection{Modulus of Elasticity}

The modulus of elasticity was determined by subjecting a cylinder specimen (Diameter; $150 \mathrm{~mm}$ and height; $300 \mathrm{~mm}$ ) to uniaxial compression by using Universal Testing Machine of capacity $1000 \mathrm{Kn}$, according to Egyptian Code for the design and implementation of concrete structures, tests guide C203 [10]. A Keithley-500 A Data Acquisition System consists of 4 channels for strain measurement and corresponding load. The deformations were measuring by dial gauges which fixed between a certain gauge length. Modulus of elasticity was found out with reference to the initial tangent drawn at the origin of the stress strain curves Figure 4. The test of modulus of elasticity was carried out for control mixture and CKD with SF mixtures. Table 4 shown the value of the modulus of elasticity after 28 days, the role of CKD with SF are observed for the increase in modulus of elasticity of mixtures; (Mix-05-15, Mix-10-15, Mix-15-15 and Mix-20-15), with ratio $43.82 \%, 28.25 \%, 17.29 \%$ and $11.32 \%$ respectively, while in mixture (Mix-25-15) modulus of elasticity are decrease with $3.13 \%$ when compared with control mixture (Mix-00-00). The modulus of elasticity is decreasing with the increasing of CKD content from $10 \%-50 \%$, the reduction of modulus of elasticity within range between (5.31\% to $77.87 \%)$ respectively [14].

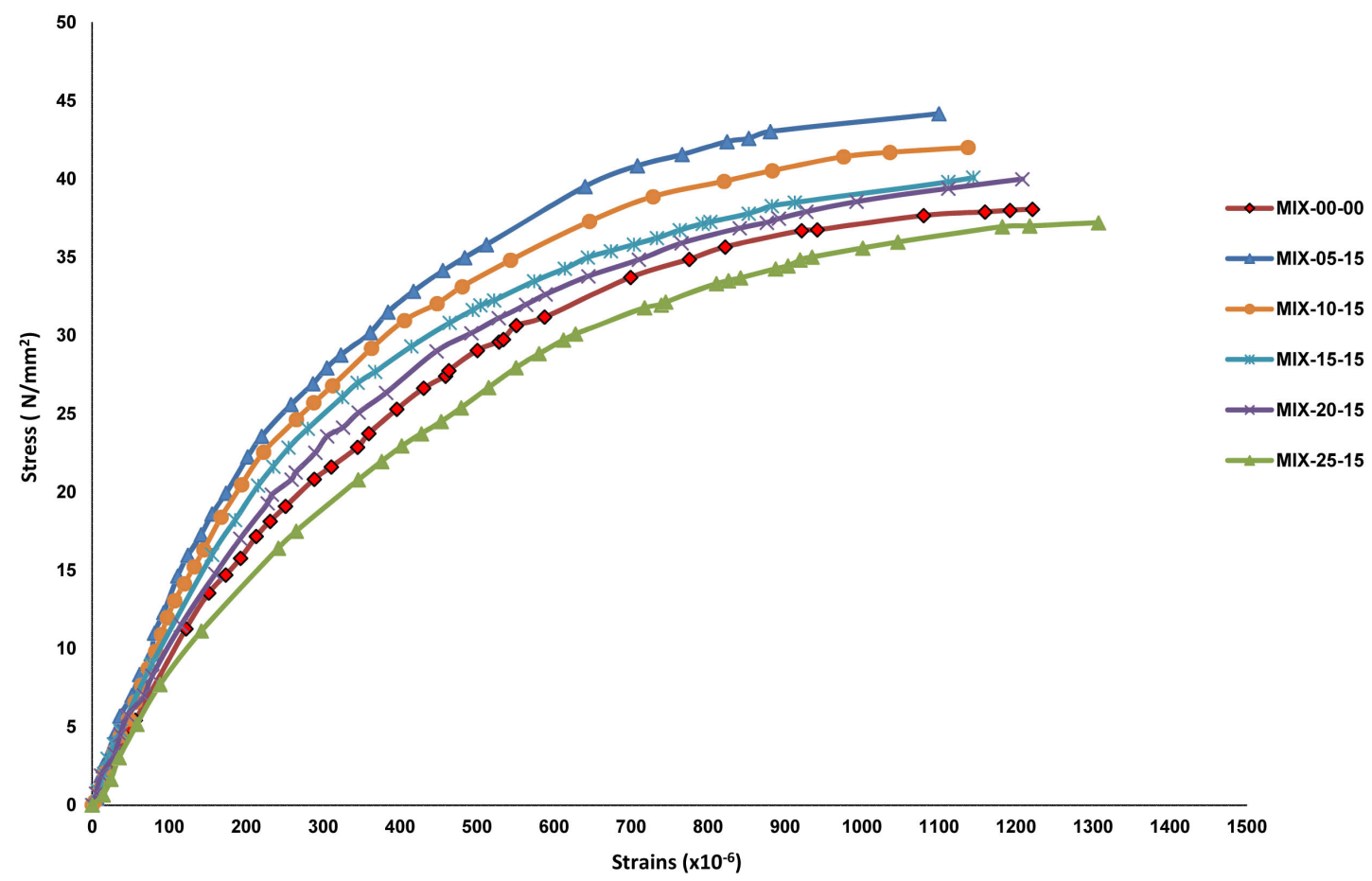

Figure 4. Stress-strain curves of mixtures contained cement kiln dust (CKD) 5\%, 10\%, 15\%, 20\% and 25\% with constant $15 \%$ silica fume (SF), compared with control mixture $0 \%$ CKD with $0 \%$ SF after 28 days. 
Table 4. Modulus of elasticity results.

\begin{tabular}{cc}
\hline Mix & Modulus of elasticity $\left(\mathrm{N} / \mathrm{mm}^{2}\right)$ \\
\hline Mix-00-00 & $30,690.997$ \\
Mix-05-15 & $44,140.411$ \\
Mix-10-15 & $39,362.098$ \\
Mix-15-15 & $35,996.615$ \\
Mix-20-15 & $34,166.211$ \\
Mix-25-15 & $29,731.258$ \\
\hline
\end{tabular}

Relationship between Modulus of Elasticity and Compressive Strength By analyzing test results statistically, the relationship between modulus of elasticity and compressive strengths after 28 days for control mixture and (CKD with SF) mixtures has been obtained as the following equations in Table 5. For (CKD with SF) mixtures the direct proportional relationship between modulus of elasticity and compressive strength are observed.

\subsection{Bond Strength}

Bond strength was describes by pull-out test, as a steel reinforcing bar $12 \mathrm{~mm}$ diameter embedded in a concrete cylinder (Diameter; $150 \mathrm{~mm}$ and height; 300 $\mathrm{mm}$ ), An anchorage length equal to $300 \mathrm{~mm}$, according to Egyptian Code for the design and implementation of concrete structures, tests guide C203 to [10]. The test is conducted in a tensile testing machine (TTM) with a capacity of $800 \mathrm{kN}$ for the direct pull out test of specimens. Specimen were inverted and positioned through the bottom platform of test machine load frame. Table 6 shows the value of bond strength and failure mode for all mixtures after 28 days. Figure 5 shows the variation of bond strength in CKD with SF mixtures when compared with control mixture. The increasing in bond strength of mixtures; (Mix-05-15, Mix-10-15, Mix-15-15 and Mix-20-15), with ratio 7.20\%, 6.21\%, $0.69 \%$ and $0.69 \%$ respectively, while in mixture (Mix-25-15) bond strength were decreases with $7.58 \%$ when compared with control mixture (Mix-00-00). Whereas by increasing ratios over ( $10 \%$ CKD with $15 \% \mathrm{SF}$ ) the failure mode changed from rebar cutting to concrete splitting.

\section{Relationship between Bond Strength and Compressive Strength}

The analysis of the present test results to determined relationship between bond and compressive strengths of (CKD with SF) concrete mixtures after 28 days, it was found within range $10.28 \%$ to $11.04 \%$, whereas $11.34 \%$ for control mixture.

\subsection{XRF Analysis}

With control mixture after 28 days. The test results are shown in Table 7. It is observed that the amount of $\mathrm{SO}_{3}$ oxide within the range $1.89 \%$ to $2.2 \%$ for all CKD with SF mixtures, and not significant when compared with control mixture $2.13 \%$. In general the use of $\mathrm{CKD}$ with $\mathrm{SF}$ in concrete mixtures lead to 


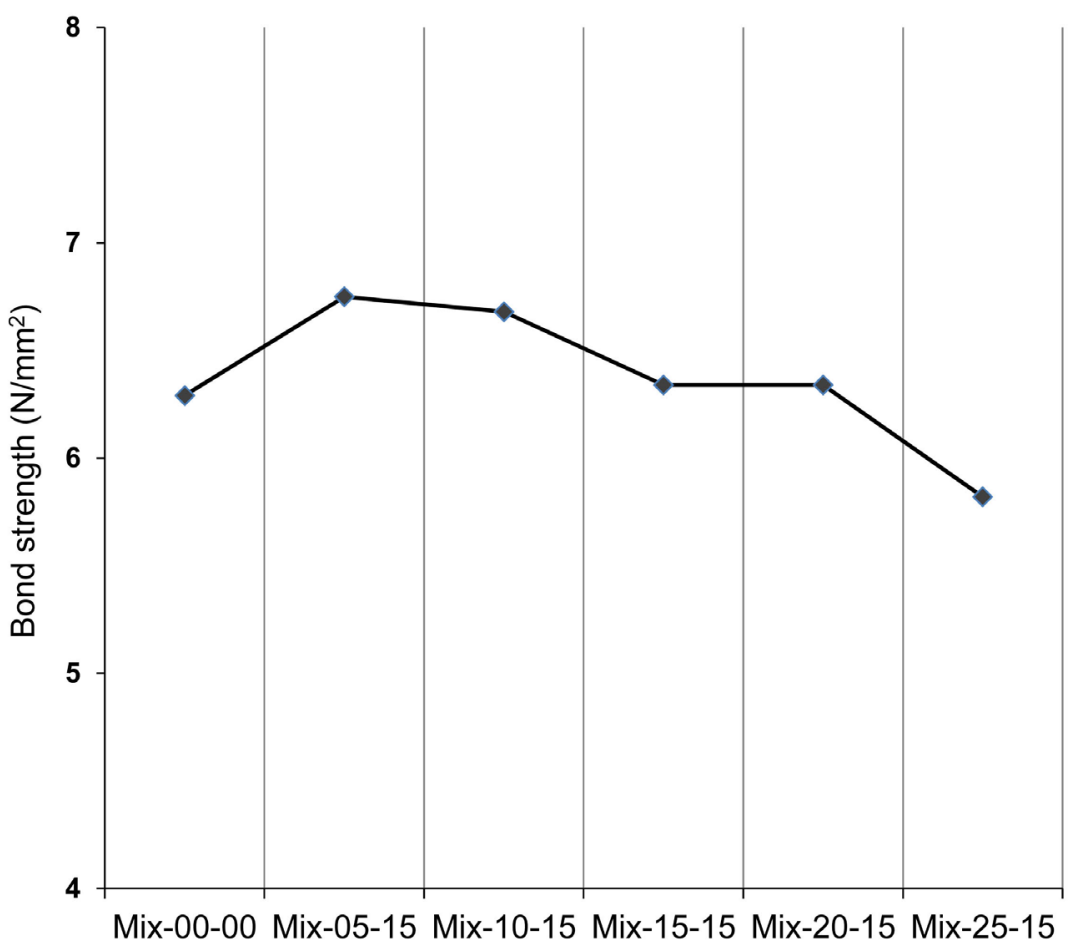

Figure 5. Bond strength of mixtures contained cement kiln dust (CKD) 5\%, 10\%, 15\%, $20 \%$ and $25 \%$ with constant $15 \%$ silica fume(SF), compared with control mixture $0 \%$ CKD with $0 \%$ SF after 28 days.

Table 5. Relationship between modulus of elasticity and compressive strength.

\begin{tabular}{cc}
\hline Mix & Relationship between $E^{*} \& F c u^{* *}$ \\
\hline Mix-00-00 & $E=4120 \sqrt{ } F c u$ MPa \\
Mix-05-15 & $E=5448 \sqrt{ } F c u$ MPa \\
Mix-10-15 & $E=5005 \sqrt{ } F c u$ MPa \\
Mix-15-15 & $E=4690 \sqrt{ } F c u$ MPa \\
Mix-20-15 & $E=4508 \sqrt{ } F c u$ MPa \\
Mix-25-15 & $E=4067 \sqrt{ } F c u$ MPa
\end{tabular}

${ }^{\star} E$ denote modulus of elasticity. ${ }^{* *} F c u$ denote compressive strength.

Table 6. Pull out test results.

\begin{tabular}{cccc}
\hline Mix & Failure load $(\mathrm{kN})$ & Bond strength $\mathrm{N} / \mathrm{mm}^{2}$ & Failure mode \\
\hline Mix-00-00 & 71.12 & 6.29 & Rebar cutting \\
Mix-05-15 & 76.24 & 6.75 & Rebar cutting \\
Mix-10-15 & 75.54 & 6.68 & Rebar cutting \\
Mix-15-15 & 71.61 & 6.34 & Concrete splitting \\
Mix-20-15 & 71.61 & 6.34 & Concrete splitting \\
Mix-25-15 & 65.73 & 5.82 & Concrete splitting
\end{tabular}


Table 7. XRF analysis results.

\begin{tabular}{ccccccc}
\hline \multirow{2}{*}{ Component } & \multicolumn{5}{c}{ Weight, \% } \\
\cline { 2 - 6 } & Mix-00-00 & Mix-05-15 & Mix-10-15 & Mix-15-15 & Mix-20-15 & Mix-25-15 \\
\hline $\mathrm{SiO}_{2}$ & 32.65 & 38.5 & 41.93 & 33.09 & 31.39 & 40.19 \\
$\mathrm{TiO}_{2}$ & 0.15 & 0.16 & 0.15 & 0.14 & 0.12 & 0.11 \\
$\mathrm{Al}_{2} \mathrm{O}_{3}$ & 1.65 & 1.6 & 1.49 & 1.58 & 1.48 & 1.33 \\
$\mathrm{Fe}_{2} \mathrm{O}_{3}$ & 2.60 & 1.6 & 1.50 & 1.80 & 1.84 & 1.53 \\
$\mathrm{Mn}$ & 0.05 & 0.05 & 0.05 & 0.05 & 0.04 & 0.04 \\
$\mathrm{MgO}$ & 6.26 & 4.41 & 2.97 & 8.02 & 8.16 & 6.58 \\
$\mathrm{CaO}$ & 34.50 & 33.8 & 33.24 & 31.14 & 31.30 & 30.21 \\
$\mathrm{Na}_{2} \mathrm{O}$ & 0.02 & 0.02 & 0.02 & 0.02 & 0.02 & 0.02 \\
$\mathrm{~K}_{2} \mathrm{O}$ & 0.25 & 0.35 & 0.35 & 0.35 & 0.35 & 0.43 \\
$\mathrm{P}_{2} \mathrm{O}_{5}$ & 0.15 & 0.06 & 0.08 & 0.06 & 0.06 & 0.08 \\
$\mathrm{Cl}$ & 0.25 & 0.3 & 0.35 & 0.35 & 0.38 & 0.38 \\
$\mathrm{SO}_{3}$ & 2.13 & 2.2 & 2.18 & 2.2 & 2.07 & 1.89 \\
$\mathrm{~L} . \mathrm{O} . \mathrm{I}$ & 19.04 & 16.69 & 15.39 & 20.90 & 22.49 & 16.91 \\
\hline
\end{tabular}

increase ratios of sulfate $\mathrm{SO}_{3}$, chloride $\mathrm{CL}$, potassium $\mathrm{K}_{2} \mathrm{O}$ and silicon $\mathrm{SiO}_{2}$. Where aluminum $\mathrm{Al}_{2} \mathrm{O}_{3}$, iron $\mathrm{Fe}_{2} \mathrm{O}_{3}$ and calcium $\mathrm{CaO}$ ratios are decreased but sodium $\mathrm{Na}_{2} \mathrm{O}$ ratio still constant when compared with control mixture. The total content of sulfates in concrete in the form of $\mathrm{SO}_{3}$, shall not exceed $4 \%$ of the weight of cement with a hardened concrete at 28 days according to ECP 203-2007 [10]. The total content of chloride ions in the form of $\mathrm{Cl}$ in non-chloride-resistant of hardened concrete, shall not exceed $0.3 \%$ of the cement weight at the 28 days [10]. The amount of $\mathrm{Cl}$ oxide in mixture (Mix-05-15) are $0.3 \%$, so that this mixture can be used in steel reinforced concrete, but the amount of $\mathrm{Cl}$ oxide in mixtures; (Mix-10-15, Mix-15-15, Mix-20-15 and Mix-25-15) within the range $0.35 \%$, this mixtures can be used in plain concrete or in FRP reinforced concrete.

\section{Conclusions}

Based on the experimental results, the following conclusions could be drawn:

- We can use industrial wastes as cement kiln dust (CKD) and silica fume (SF) to produce economic concrete.

- In general, a partial replacement of cement with CKD and SF leads to decrease of fresh concrete workability. It was observed the slump decreased with increasing ratio of CKD with constant $15 \%$ of SF in concrete mixtures.

- The amount of $20 \%$ CKD in the presence of $15 \%$ SF as a partial replacement by weight of cement is the optimum ratios which can be used in concrete mixtures without lowering on compressive, split tensile and flexural strength at all the ages of concrete. Also modulus of elasticity and bond strength in- 
creased by $11.32 \%$ and $0.69 \%$ respectively after 28 days when compared with control mixture.

- At amount of $25 \%$ CKD in the presence of $15 \%$ SF as a partial replacement by weight of cement in concrete, a slight decrease was observed in compressive, split tensile and flexural strength within the range (3.69\% to $7.69 \%)$ at all the ages of concrete. But bond strength and modulus of elasticity decreased by $7.58 \%$ and $3.13 \%$ respectively after 28 days when compared with control mixture.

- In concrete mixtures which contain different ratios of CKD and constant ratio $15 \%$ of SF as a partial replacing by weight of cement at the age of 28 days, it has been observed that split tensile strength equals $10.6 \%$ to $10.76 \%$ from compressive strength, flexural strength equals $14.55 \%$ to $14.88 \%$ from compressive strength and bond strength equals $10.28 \%$ to $11.04 \%$ compressive strength.

- By analyzing test results statistically of CKD with SF concrete mixtures, the directly proportional relationship between modulus of elasticity and compressive strength is observed. The relationship between modulus of elasticity and compressive strength at the age of 28 days, can be given with equations, $E=(4067-5448) \sqrt{F c u} \mathrm{MPa}$, depending on decreasing of CKD ratio (where $E$ and $F c u$ denote modulus of elasticity and compressive strength respectively).

- From XRF analysis, it was observed the use of CKD with SF with gradually increased ratios in concrete mixtures led to increasing ratios of sulfate $\mathrm{SO}_{3}$, chloride $\mathrm{CL}$, potassium $\mathrm{K}_{2} \mathrm{O}$ and silicon $\mathrm{SiO}_{2}$, where aluminum $\mathrm{Al}_{2} \mathrm{O}_{3}$, iron $\mathrm{Fe}_{2} \mathrm{O}_{3}$ and calcium $\mathrm{CaO}$ ratios are decreased but sodium $\mathrm{Na}_{2} \mathrm{O}$ ratio is still constant when compared with control mixture.

\section{Acknowledgements}

Authors would like to thank AL-AZHAR UNIVERSITY - Faculty of ENGINEER (materials laboratory) for helping to carry out experimental testing of this research.

Special thanks to Assistant Professor, Dr. MOHAMMED TAHA NOOMAN, Faculty of Engineering, Al-Azhar University, Cairo, Egypt for his great assistance during the conduct of this work, valuable revisions, his directions in the presentation and analysis of test results. His effort is highly appreciated.

\section{Conflicts of Interest}

The authors declare no conflicts of interest regarding the publication of this paper.

\section{References}

[1] Pradhan, D. and Dutta, D. (2013) Effects of Silica Fume in Conventional Concrete. International Journal of Engineering Research and Applications, 3, 1307-1310.

[2] Hassan, I.H., Abdul-Kareem, O.M. and Shihab, A.Y. (2013) Utilization of Cement 
Kiln Dust (CKD) as a Partial Replacement of Cement in Mortar and Concrete. $A L$ Rafdain Engineering Journal, 21, 72-87.

[3] Marku, J., Dumi, I., Lico, E., Dilo, T. and Çakaj, O. (2012) The Characterization and the Utilization of Cement Kiln Dust (CKD) as Partial Replacement of Portland Cement in Mortar and Concrete Production. Zaštita Materijala, 53, 334-345.

[4] Kumar, R. and Dhaka, J. (2016) Review Paper on Partial Replacement of Cement with Silica Fume and Its Effects on Concrete Properties. International Journal for Technological Research in Engineering, 4, 83-85.

[5] Roy, D.K.S. and Sil, A. (2012) Effect of Partial Replacement of Cement by Silica Fume on Hardened Concrete. International Journal of Emerging Technology and Advanced Engineering, 2, 472-475.

[6] Commitee, A.C.I. (1995) Guide for the Use of Silica Fume in Concrete. ACI Materials Journal, 92, 437-440. https://doi.org/10.14359/978

[7] The Egyptian Standard Specifications for Concrete Aggregates 1109/2002.

[8] The Egyptian Standard Specifications 4756/2013. Testing the Physical and Mechanical Properties of Cement.

[9] ECP 203-2007 (2007) Egyptian Code for Design and Construction of Reinforced Concrete Structures, Design of Concrete Mixes (2-28) to (2-34).

[10] Egyptian Code for the Design and Implementation of Concrete Structures 2007, Tests Guide C203.

[11] Ghutke, V.S. and Bhandari, P.S. (2014) Influence of Silica Fume on Concrete. International Conference on Advances in Engineering \& Technology-2014 (ICAET 2014), 45-47.

[12] Al-Harthy, A.S., Taha, R. and Al-Maamary, F. (2003) Effect of Cement Kiln Dust (CKD) on Mortar and Concrete Mixtures. Construction and Building Materials, 17, 353-360. https://doi.org/10.1016/S0950-0618(02)00120-4

[13] Sharif, S.F.A. (2011) Influence of Cement Kiln Dust as Partial Replacement on Some Properties of Ordinary and White Portland Cement. Tikrit Journal of Engineering Sciences, 18, 23-32.

[14] Mohammad, A.M. and Hilal, N.N. (2010) Re-Using the By-Product of Cement Industry (Cement Kiln Dust) to Produce the Concrete. Anbar Journal for Engineering Sciences, 3, 1-14.

[15] Udoeyo, F.F. and Hyee, A. (2002) Strengths of Cement Kiln Dust Concrete. Journal of Materials in Civil Engineering, 14, 524-526. https://doi.org/10.1061/(ASCE)0899-1561(2002)14:6(524)

[16] Bhanja, S. and Sengupta, B. (2005) Influence of Silica Fume on the Tensile Strength of Concrete. Cement and Concrete Research, 35, 743-747. https://doi.org/10.1016/j.cemconres.2004.05.024

[17] Amarkhail, N. (2015) Effects of Silica Fume on Properties of High-Strength Concrete. International Journal of Technical Research and Applications, 32, 13-19. 